\title{
EVALUATING THE PERFORMANCE OF A MODIFIED GRAIN COMBINE HARVESTER USED FOR SUNFLOWER CROPS
}

\author{
EL SAYED, G. H. ${ }^{1}$, M. A. F.ABD EL MAKSOUD ${ }^{2}$ AND S.A.H.M.SHALABY ${ }^{1}$
}

1 Ag. Eng.Res. Inst., ARC,Dokki, Giza

2 Ag. Eng. Dep., Fac. Of Ag., Menoufiya Univ.

(Manuscript received 16 June 2009)

\begin{abstract}
The performance of a small modified European grain combine harvester CICORIA, in harvesting sunflower Crop was investigated. Effects of some important parameters such as combine forward speed, seed moisture content, harvesting direction, rotor speed, and rotor-concave clearance on the combine performance were studied. Results showed that the optimum condition obtained at forward speed of $3.3 \mathrm{~km} / \mathrm{h}$, seed moisture content of $15.15 \%(\mathrm{db})$ Results also indicated that total seed loss of $40.02 \mathrm{~kg} / \mathrm{fed}$, energy requirements of (11.38 kW.h/ton), seed production of $1739 \mathrm{~kg} / \mathrm{h}$, fuel consumption of $5.5 \mathrm{~L} / \mathrm{h}$ and total combine processing efficiency of $97.27 \%$ were obtained .
\end{abstract}

\section{INTRODUCTION}

The shortage of oil production in Egypt is often about $87 \%$ of the total consumption (Counselor and Attach Reports, Official Statistics USDA Estimates, 2002). Sunflower (Helianthus annus L.) was seen as one of the best plants among oil crops which may solve this problem. Sunflower is considered a unique crop in its adaptability to be planted beside other crops. It can be grown in salinity and all types of soil and it can stand water shortage. It can be planted more than one time at the same year. In Egypt, sunflower will be the most important oil crop to face the deficiency of vegetable oils because it could be cultivated in the newly reclaimed areas Keshta et al., 1993.

The FAOSTAT, Data Base Results-CSV File-FAO 2004 recorded that the sunflower planted area in Egypt reached about 37249 feddans with total production reached to about $35350 \mathrm{Mg}$ of seeds.

Evidently, sunflower mechanical harvesting has no chance of wide scale adaptation especially in Egypt. This may be due to the following reasons by Moskalenko, 1976:

1.The great height of plants, (about two meters).

2.The weight of relative mass $(1000-2500 \mathrm{~kg} / \mathrm{ha})$.

3.The stalk's high resistance for cutting, requiring shear force ranging from 40-100 kg depending on the stalk's diameter.

4. The high moisture content of seeds and heads. 
5.The high losses due to exposure to birds and weather. These features make it necessary to construct special machines for sunflower harvesting suitable to our farms or constructing changeable parts for cereal crops Combine Harvesters. In fact, the traditional method for sunflower harvesting process is still done manually. The process consists of cutting heads, transporting and drying desks from7to15days. The threshing of heads is done by two methods, manually by hands or by stationary threshing machines. Winnowing seeds is achieved by two methods, isolating them by hand actuated screens or traditional blowing machine. Each operation as previously explained has a part of time and seed losses, not economical and do not encourage high production and product of high quality.

However, many research works had been conducted to evaluate sunflower threshing, a very few research works have been directed to evaluate the mechanical sunflower harvesting. Moreover, in Egypt the Ministry of Agriculture, 1990, reported that in case of sunflower harvesting, operations before full maturity are difficult to manage because of the too big amount of green matter. So, to solve this problem, the combine harvester must be equipped with special attachments with turned up edges, deflectors and dividers for less moisture harvesting.

Therefore, the general objective of this study was:

Studying and evaluation the possibility of mechanical harvesting of sunflower crop by using a modified cereal crops harvester under moisture contents of seeds ranged from about 25 to $10 \%$ (dry bases), and levels of harvesting speed .In this direction, Culpin ( 1986 ) reported that it is no longer most economic to delay the start of harvest until the grain can be brought in at a safe storage moisture content without the need for drying.

\section{REVIEW OF LITERATURE}

Economic Commission for Europe FAO-UN (1986) indicated that, harvesting is done with grain combines fitted with special header attachments for sunflowers. Operating speed depends on plant density, type of combine headers and moisture content of over 20 percent. Plant protection also plays a part in successful harvesting as rotten heads are particularly sensitive to mechanical action, and can lead to a step rise in harvesting losses.

El-Sayed et al. (2002) reported that the total losses increased form 5.5 to $5.9 \%$ by increasing the forward speed from 1.7 to $2.7 \mathrm{~km} / \mathrm{h}$ by using the general purpose combine harvester in sunflower harvesting.

Dobresc et al. (1974) studied sunflower mechanical harvesting in Romania, they said that, as a result of the experiments carried out with the three types of sunflower 
harvester attachments, which made in Romania. The (0-12) self-propelled cereal combine-harvester equipped with one of the three attachments can be used with good results in sunflower crop harvesting. The combine harvesting output is of 20-25 ton/day.

Arnul (1990) reported that the conventional combine harvester should be provided with separate sections converse its major working components and the necessary modification for harvesting alternative crops such as sunflower.

Georgiey (1990) studied the difference between two types of combine harvester used for sunflower harvesting. He stated that the rotary combine harvester has threshing system is more gentle, giving a considerable reduction in mechanical damage than the other combine with conventional drum-type (tangential type).

Trubilin and Kravchenko (2001) studied the feasibility of using the reaper units of the grain combines for the harvesting of sunflowers. They indicated that the reaper units should incorporate trough type separators, extra partitions between the central shaft of the reel and the rakes, and shields covering the rake tines. The reel drive should ensure satisfactory cutting of the stem at combine speeds of 1.5 to $4.0 \mathrm{~km} / \mathrm{h}$.

Szendro et al. (1990) said that, combine harvesters used for cereals can also be used for sunflower harvesting but the forward speed can not be increased because of header losses

Mohamed (1991) indicated that, a reverse relation was existed between feed rate and crop moisture contents, but there was direct relation between feed rate and cylinder speeds. The grain output is directly proportional to the feed rate.

Anil et al. (1998) designed and developed a threshing machine for sunflower seeds. They concluded that, the percentage of visible damage increased with cylinder speed and decreased with feed rate. The percentage of un-threshed grain increased with feed rate and decreased with cylinder speed. Output capacity increased with cylinder speed and feed rate, cleaning efficiency increased with cylinder speed and increased with decreasing feed rate. Grain loss decreased with feed rate and increased with cylinder speed.

Naravani (1987) studied the performance of a mini thresher for sunflower at moisture content of seeds ranged from 34 to $4.5 \%$ (w.b.). The highest threshing capacity of $132.0 \mathrm{~kg} / \mathrm{h}$ was obtained at $7.5 \%$ (M.C.). Threshing efficiency increased from 87.5 to $97.43 \%$ as the seed (M.C) decreased from $34 \%$ to $7.5 \%$.

Schuler et al. (1976) showed that to minimize harvesting losses, much of the sunflower crop is harvested when the moisture content of the seeds is 16 percent (wet base) or higher. 
Kumar and Goss (1977) reported that at high forward speeds the processing seed loss from the combine increases rapidly which raises the cost, whereas at low speeds high timeliness crop losses increase the harvesting cost. They added that at $1 \mathrm{~km} / \mathrm{h}$ forward speed more than 16 days are required to harvest 260 ha (with four combines) whereas only 4 days are needed at $5 \mathrm{~km} / \mathrm{h}$. A speed of $2.5 \mathrm{~km} / \mathrm{h}$ results in the maximum net return.

Dragos (1979) indicated that the threshing drum operating power was $45.5 \%$ from the total power of the combine harvester. However, he added that the needed power to separate the grain was $15.18 \%$ from the total power to operate the combine.

Baev et al. (2001) concluded that the energy consumption of sunflower harvesting using direct combining was (104503 MJ/100 ha).

Toth and Liker (1992) developed a new technology which reduces the energy requirement for sunflower harvesting. A sunflower harvesting adapter equipped with a stalk shredder was mounted on a combine harvester fitted with a straw cutter. During harvesting, the sunflower stalks were cut in a single pass and crop residues were spread uniformly on the stubble by the machine. Therefore, an additional pass for stalk shredding is not necessary.

Kaul and Egbo (1985) stated that machine costs can be worked out on the basis of two items: Fixed costs and operating costs.

There are three different ways to calculate depreciation as following:

Straight line depreciation, Sum of the digits depreciation and Declining balance deprecation. They mentioned that the variable or operating costs are Repair and maintenance, Fuel and oil and Labor.

Awady et al. (1982) reported that the criterion cost can be calculated using the following formula:

Criterion cost $(\mathrm{LE} /$ fed. $)=$ Total Cost $(\mathrm{LE} /$ fed. $)+$ Losses cost $(\mathrm{LE} / \mathrm{fed}$.$) .$

Kapustin and Kunakov (2004) concluded that the efficiency of sunflower harvesting depended on many factors, above all, it was necessary to reduce the number of factors affecting the header to a minimum (1-2).

\section{MATERIALS AND METHODS}

An original combine harvester (CICORIA) of cereal crops ( $T$ ) type, model longitudinal axial-flow, with standard 5 bat reel, was used after modification of its header and threshing devices in previous studies was used as sunflower harvester in this investigation Shalaby, 2006. 


\section{Methods of measurements}

\section{Measurement of factors:}

\section{a. Seed moisture content, (\% dry basis):}

It was measured on harvesting day by two methods.

1. Directly, by using electric moisture tester Model $400 \mathrm{~B}$.

2. The drying method by using an electric oven according to the ASAE standard $\left(130^{\circ} \mathrm{C}\right.$ for 1 hour).

The treatments on moisture samples were determined using the oven method to check the electric tester. The differences between the two methods were about \pm $0.2 \%$.

$$
\mathrm{MC}(\% \mathrm{~d} . \mathrm{b})=\frac{\text { Sample weight before drying }- \text { sample weight drying }}{\text { Sample weight before drying }}
$$

\section{b. Combine forward speed, (S), $\mathrm{m} / \mathrm{s}$ :}

The combine forward speeds were measured during harvesting operation using a digital stop watch to record the time needed for travel a distance of thirty five meters long. The lost time as in turning, repairing and cleaning was recorded also $\mathrm{S}=\frac{3.6 \text { distance }(\mathrm{km})}{\text { time consumed }(\mathrm{h})}=\mathrm{km} / \mathrm{h}$

\section{The threshing-rotor speed, $(\mathrm{T}), \mathrm{m} / \mathrm{s}$ :}

The rotor speed was measured directly in R.P.M. using a speed-meter (dial tachometer).

$\mathrm{T}=$ R.P.M $\mathrm{M} \Pi \times \mathrm{D} / 60 \mathrm{~m} / \mathrm{s}$, Where: $\mathrm{D}=$ Rotor diameter, $\mathrm{m}$

\section{d. The concave-rotor clearance ratios, (C):}

The concave is divided originally into equal three sections, each of them can be adjusted alone by the meaning of the relation (inlet $\mathrm{cm} /$ outlet $\mathrm{cm}$ ) clearance ratio using thickness measuring fillers.

e. harvesting directions, (D),

Generally, the harvesting operations were done perpendicular to sowing direction in order to redeem the action of stem lodging

\section{Measurements of the modified combine harvester performance:}

\section{The total harvesting losses, \%:}

Total harvesting losses, $\%=$ header losses, $\%+$ threshing losses, $\%+$ separating losses, $\%+$ cleaning losses, $\%$. 


\section{Harvesting efficiency, \%:}

1. Reaping efficiency $(\%) \quad=100$-header losses.

2. Threshing efficiency $(\%) \quad=100$-threshing losses.

3. Separating efficiency $(\%) \quad=100$-separating losses.

4. Shoe efficiency $(\%)=100$-shoe losses.

5. Harvesting efficiency $(\%) \quad=100$-total harvesting losses

$=$ Total efficiency of (header + thresher + separator + shoe $), \%$.

\section{Evaluation of the machine efficiency: (ME), \%:}

The efficiency of the modified harvester machine was determined by measuring machine output and machine losses.

ME $\%=\frac{\text { Output }}{\text { Output }+ \text { combine losses }}$

\section{Breakage percent (visible and invisible damage \%):}

The tests for damage estimation were done on three samples of seeds for each plot and the mean results indicated that there were neither visible nor invisible damage in the samples under the research conditions.

5. Machine field efficiency \%,( Kepner et al, 1982):

1. Machine theoretical field capacity, effective field capacity and machine field efficiency were calculated.

\section{6 -Fuel consumption determinations: $\left(F_{t}\right)$ :}

The following procedure was followed for measuring fuel consumption throughout harvesting operations:

1. The combine fuel tank was completely filled with fuel.

2. The operation was then carried out, the time needed was recorded with a stopwatch and the harvested area was measured and calculated.

3. At the end of each operation, the combine tank was refilled with a known quantity of fuel.

4. The fuel consumption per unit time or unit area can be calculated as follows: $F_{t}=\frac{f}{t} \quad L / h$.

\section{Where:}

$\mathrm{F}_{\mathrm{t}} \quad=$ the fuel consumption per unit time, L/hours,

$\mathrm{f}=\quad=$ the quantity of fuel consumed throughout the work, $\mathrm{L}$

$\mathrm{t}=$ time of work, hours.

\section{Energy requirements: $(E):$}

It was calculated by using the following equation (Taieb, 1990).

$$
E=F_{c} \times \frac{1}{60 \times 60} \times \rho_{f} \times \text { L.C.V } \times 427 \times \frac{1}{75} \times 0.735 \times \eta_{\text {th }} \times \eta_{m} \times \frac{1}{\mathrm{~Pa}}(k W . h / \text { fed. })
$$




\section{Where:}

\begin{tabular}{|c|c|}
\hline $\mathrm{F}_{\mathrm{c}}$ & = Fuel consumption, L/h, \\
\hline$\rho_{f}$ & $=$ Density of fuel, $\mathrm{kg} / \mathrm{L},($ for diesel fuel $=0.85)$ \\
\hline C.V & $=$ Calorific value of fuel, $\mathrm{KCal} / \mathrm{kg}$, (for diesel fuel $=10000$ ) \\
\hline 427 & $=$ Constant (thermo mechanical equivalent), kg.m/KCal, \\
\hline 0.735 & = coefficient for changing from HP to $\mathrm{kW}$, \\
\hline$\eta_{\text {th }}$ & $=$ Thermal efficiency of engine. \\
\hline$\eta_{\mathrm{m}}$ & $=$ Mechanical efficiency of engine ( $80 \%$ for diesel engine), \\
\hline & $=$ Actual productivity, fed/h. \\
\hline
\end{tabular}

\section{Specific energy requirement:}

It was calculated using the following equation

\begin{tabular}{|c|c|c|c|}
\hline & $\begin{array}{c}\text { Energy requiremesn } \\
\text { perfeddan }\end{array}$ & Kw.h/fedda & Kw.h \\
\hline ecric entergy & Productivity perfeddan & $\begin{array}{l}\text { Ton / } \\
\text { fessan }\end{array}$ & ton \\
\hline
\end{tabular}

\section{5- Cost evaluation of the combine harvester:}

The following items were used in this investigation:- purchase price, working life and working hours - for the combine harvester are according to 2003 prices as shown in Table (1):

Table 1. Price, working life and working hours - for the combine harvester are according to 2003 prices

\begin{tabular}{|c|c|c|c|}
\hline Items & $\begin{array}{c}\text { Purchase } \\
\text { price } \\
\text { (EGYP) }\end{array}$ & $\begin{array}{c}\text { Working life } \\
\text { (years) }\end{array}$ & Working hours/year (h/year) \\
\hline Type: Combine harvester & 300000 & 10 & \\
\cline { 1 - 2 } Sunflower harvesting & & & $\begin{array}{c}\text { seasons } \times \text { Days } \times \text { Hours } \\
(\mathrm{S}) \times 30(\mathrm{D}) \times(\mathrm{H})=240\end{array}$ \\
\hline Wheat harvesting & & & $1 \times 30 \times 8=240$ \\
\hline Alfalfa harvesting & & & $1 \times 30 \times 8=240$ \\
\hline Total & & & $1200 \mathrm{~h} / \mathrm{y}$ \\
\hline
\end{tabular}

\section{(1) The fixed costs included:}

1. Depreciation 2. Interest 3. Insurance 4. Taxes 5. Sheltering

\section{(2) The variable costs "operating costs" included:}

1. Fuel 2. Grease 3. Lubricant 4. Repair and maintenance 5. Labors.

\section{Calculations of fixed costs:}

Depreciation and interest costs have been calculated using straight line method as follows (Kepner et al., 1982).

(1) $D=\frac{P-S}{N} \ldots \ldots . . . E G Y P / h$ 
Where: D: Depreciation cost, EGYP /h, P: Purchase price, EGYP

S: Salvage value, $10 \%$ of purchase price, $\mathrm{N}$ : Total life, in hours.

2. Interest on investment $=\frac{\mathrm{P}+\mathrm{S}}{2 \mathrm{~L}} \times \frac{\mathrm{R}}{100} \mathrm{EGYP} / \mathrm{h}$

Where: $\frac{\mathrm{P}+\mathrm{S}}{2}=$ Average investment, EGYP/h.

$L$ : Yearly wear out life, hours per year,

$\mathrm{R}$, Rate of interest, the proposed value,

3. Taxes, insurance and shelter (TIS):

For taxes, insurance and shelter a total annual charge equal to $2 \%$ of the purchase price is suggested where the straight line depreciation is used (Kepner et al., 1982). So, taxes, insurance and shelter hourly cost for each used machine will be calculated as follows:

$(\mathrm{TIS})=\frac{\mathrm{P}}{\mathrm{L}} \times 0.02 \mathrm{EGYP} / \mathrm{h}$

Where:

TIS : Taxes, insurance and shelter cost, EGYP/h

The total fixed costs (TF) are the sum of depreciation cost, interest cost, taxes, and insurance and shelter costs as follows:

$(T F)=D+I+(T I S) \quad E G Y P / h$

\section{Calculations of variable costs:}

1. Fuel and lubricant (FL):

The fuel costs ( $\mathrm{f}$ ) calculated as follows:

Fuel costs $(F)=$ Fuel consumption Lit/h $x$ Fuel price EGYP / lit.

While, total cost of oil, filters and grease can be taken as $15 \%$ of the fuel cost (Kepner et al., 1982) and then,, lubricant cost (L) 0.15 F.

2. Repair and maintenance costs (RM):

The repair and maintenance costs were calculated as a percentage of $80-100 \%$ of depreciation. The percentage of $90 \%$ was used in this work

3. Labors cost (La):

The cost of labors was calculated according to the prevalence wage rates for local labors which was found to be $5 \mathrm{EGYP} / \mathrm{h}$

The total operating costs $(\mathrm{TO})=\mathrm{RM}+\mathrm{FL}+\mathrm{La} \ldots$.

\section{Annual cost of the combine:}

In the present study, the cost evaluation was performed considering the conventional of evaluating both fixed and variable costs (Hunt, 1973). According to 2006 price levels.

Criterion cost $=$ Anual costs + losses costs $+\mathrm{EGPP} / \mathrm{Y}$ 


\section{RESULTS AND DISCUSSION}

Evaluating the performance of the modified harvesting combine under different levels of forward speed and seed moisture contents:

Effect of seed moisture content, forward speed, rotor speed and clearance ratio on total losses and efficiency:

Figure (1) shows clearly that the lowest values of total losses and consequently the increasing values of harvesting efficiency \% as shown in Figure (2) were determined at seed moisture content of $15.15 \%$ (d.b), forward speed of $3.30 \mathrm{~km} / \mathrm{h}$, rotor speed of $13.49 \mathrm{~m} / \mathrm{s}$ (489 RPM)and clearance ratio of $\left(C_{1}=1.5\right)$. These results may be related to the optimum quality and quantity of the plant mass fed to the machine and the uniformity of feeding. This result also means that the plant mass is displaced uniformity not only in the plane of rotation of the drum but also in its axial direction. Consequently, the charge in the drum performs a series of cyclic operations and repeated impacts are resulted. The grain is threshed and separated due to these impacts and the movement of the charge between the surface of the beaters and the bars of the concave. This result when considering clearance ratio of $C_{1}$ may be explained as following: during the threshing operation, the charge is fed to the threshing drum, the beaters which run at a speed greater than that of the plant mass, strike the latter and thresh out parts of the grain. Simultaneously, the drum takes up the mass and draws it through the gab between the beaters and the concave bars. Grain is threshed out during this process also. The plant mass moves through the space between the drum and the concave at a speed lower than the speed of the beaters. Hence, the plant mass is subjected to continuous impact. The efficiency of grain threshing increases with increase in the number of impact and in the threshing gap as shown in Figure (2). The charge of this gap effects not only on the grain yield but also on the deformation of the stalks. The regression analysis of data indicated the same trend of results and generally both machine forward speed $(\mathrm{km} / \mathrm{h})$ and seed moisture content (\% d.b) were directly proportional while both rotor speed $(\mathrm{m} / \mathrm{sec})$ and clearance ratio were inversely proportional with total losses as the following :

where :

Tot.L , $\%=$ percent of total harvesting losses .

Tot.Ef, $\%=$ percent of total harvesting efficiency .

$\mathrm{S} \quad=$ forward speed $\mathrm{km} / \mathrm{h} \quad, \quad \mathrm{T}=\operatorname{rotor}$ speed $\mathrm{m} / \mathrm{s}$.

MC = present of seed moisture content (d.b).

C $\quad$ rotor - concave clearance: $\left(C_{1}=1.5, C_{2}=1.3\right)$. 


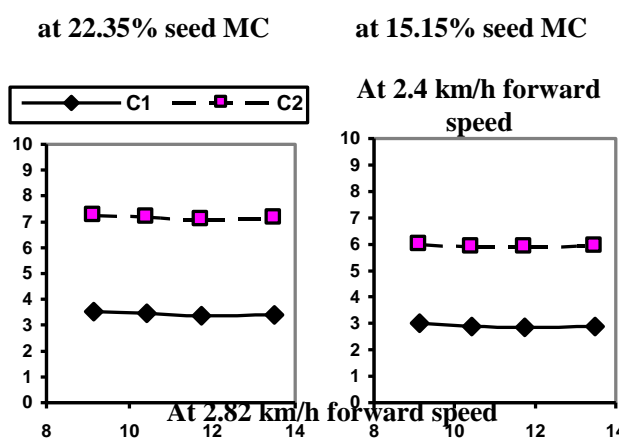

at $10.75 \%$ seed MC
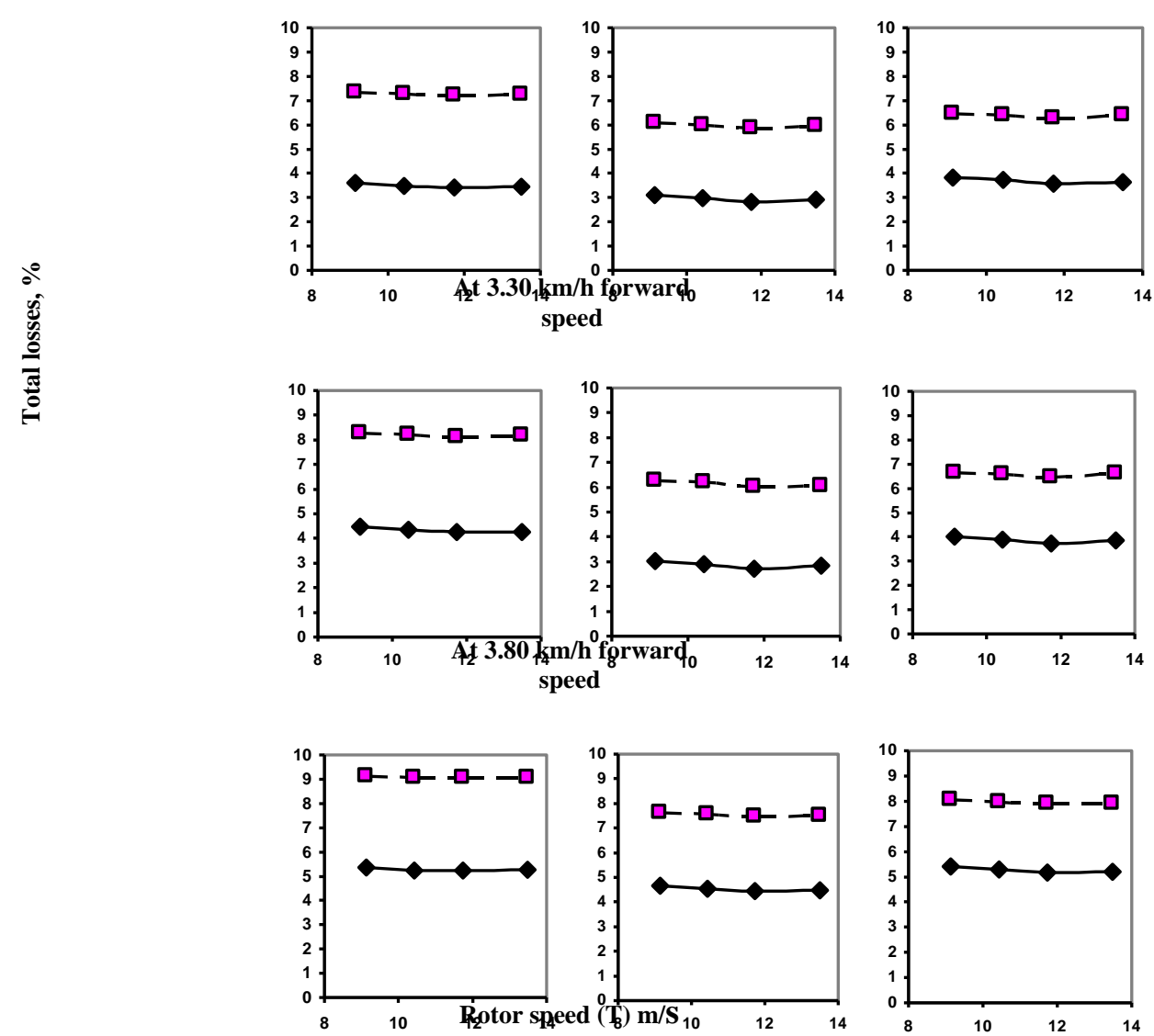

Figure 1. Effect of rotor speed and rotor-concave clearance ratio on total losses, at different forward speed and seed moisture contents $\left(c_{1}=1.5, c_{2}=1.3\right)$. 

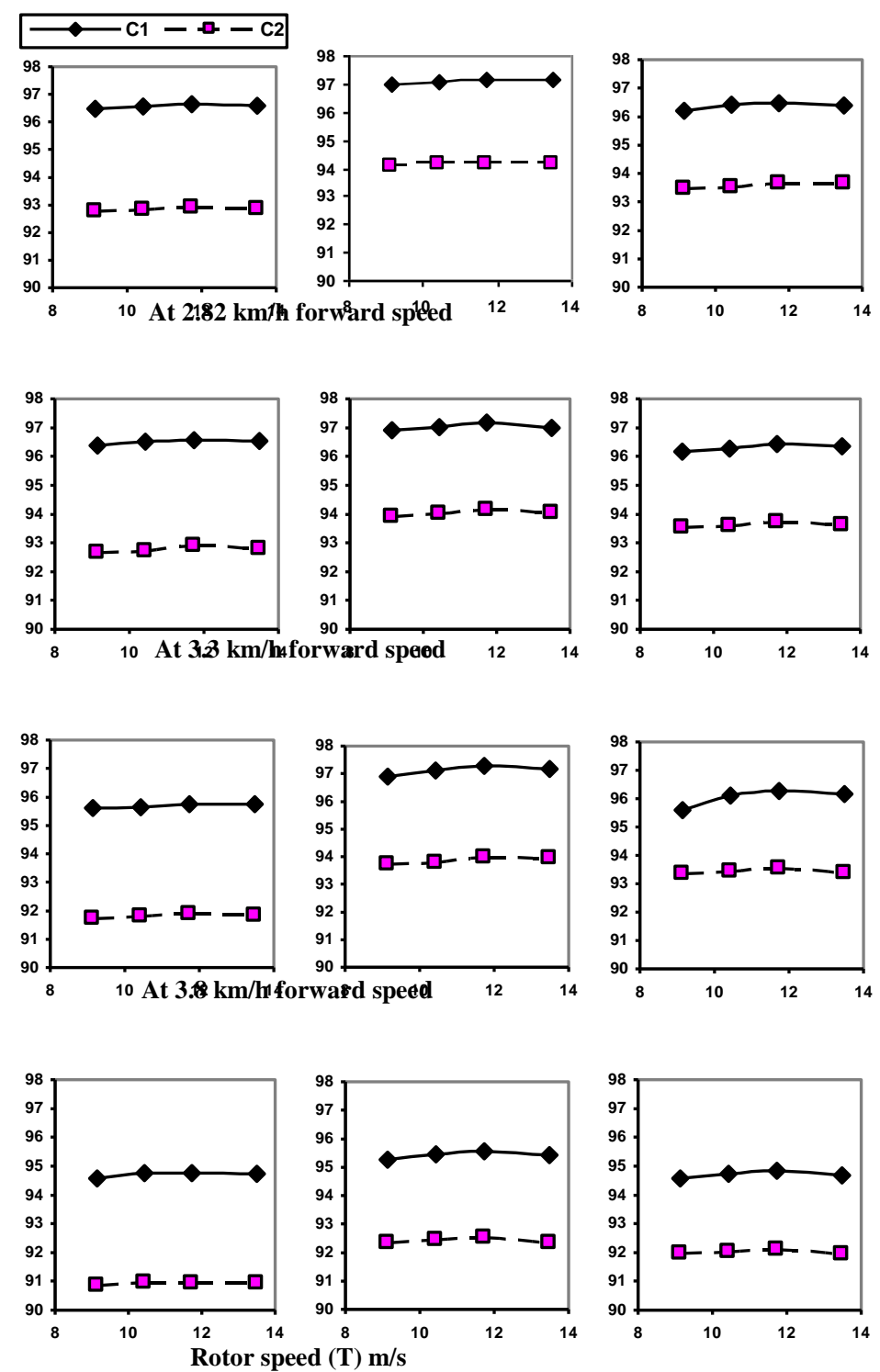

Figure 2. Effect of rotor speed and rotor-concave clearance ratio on harvesting efficiency, at different forward speeds and seed moisture contents $\left(c_{1}=\right.$ $\left.1.5, c_{2}=1.3\right)$.

Effect of combine forward speed and seed moisture content on seed production $(\mathrm{kg} / \mathrm{h})$ at the recommended parameters of $\mathrm{T}=11.73 \mathrm{~m} / \mathrm{s}$ and $\mathrm{C}$ ratio $=1.5:$

\section{Forward speed:}

Figure (3) shows that the combine forward speed has a changeable influence on its seed production under the same level of seed moisture content. It is observed that 
when harvesting at moisture content of 22.35 (d.b) by forward speed of $2.4 \mathrm{~km} / \mathrm{h}$, the seed production is $1421.64 \mathrm{~kg} / \mathrm{h}$. Increasing the forward speed from 2.4 to $3.30 \mathrm{~km} / \mathrm{h}$ increases the seed production to $2021.96 \mathrm{~kg} / \mathrm{h}$ (the increment is about $600 \mathrm{~kg} / \mathrm{h}$ ). While increasing the forward speed from 3.30 to $3.80 \mathrm{~km} / \mathrm{h}$, the seed production decreased from $2021.96 \mathrm{~kg} / \mathrm{h}$ to $1935.36 \mathrm{~kg} / \mathrm{h}$ (the decrement is about $86 \mathrm{~kg} / \mathrm{h}$ ). This can be explained by increasing he forward speed increases the header losses which results a decrement in the total seed production. This result means that the forward speed of $3.30 \mathrm{~km} / \mathrm{h}$ is recommended for obtain the higher amount of seed productivity when harvesting under the higher level of seed moisture content of $22.35 \%$.

\section{Moisture content:}

Figure (3) shows that seed moisture content affect the seed production under the same forward speed. It is noted that when harvesting by the forward speed of 3.3 $\mathrm{km} / \mathrm{h}$ under seed moisture content of 22.35 (\% d.b), the seed production is 2021.96 $\mathrm{kg} / \mathrm{h}$., decreasing the seed moisture content to 15.15 decreases the seed production to $1735 \mathrm{~kg} / \mathrm{h}$ (the decrement is about $331 \mathrm{~kg} / \mathrm{h}$ ). While more decreasing of the seed moisture content to 10.75 , the seed production decreased to $1511.40 \mathrm{~kg} / \mathrm{h}$ (the decrement is about $228 \mathrm{~kg} / \mathrm{h}$ ). This may be due to the bird attack and weather conditions at late harvesting. Also, due to the inclining condition of the sunflower heads. This result means that the seed moisture content of $22.35 \%$ d.b is recommended as optimum for the higher amount of seed productivity when harvesting by the forward speed of $3.30 \mathrm{~km} / \mathrm{h}$.

The regression analysis of data clarified the same trend of results. The following regression equation revealed that there are differences between means of seed productivity $(\mathrm{kg} / \mathrm{h})$ as affected by the different levels of both machine forward speed $(\mathrm{m} / \mathrm{s})$ and seed moisture content(\% d.b):

S. Prod, $(\mathrm{kg} / \mathrm{h})=-100+1300 \mathrm{~S}+39 \mathrm{MC} \quad\left(\mathrm{R}^{2}=0.89\right)$

Where: S.Prod $=$ Seed Productivity, $(\mathrm{m} / \mathrm{s})$,

$\mathrm{S} \quad=$ forward speed, $(\mathrm{km} / \mathrm{h})$,

MC, \% = percent of seed moisture content (d.b). 

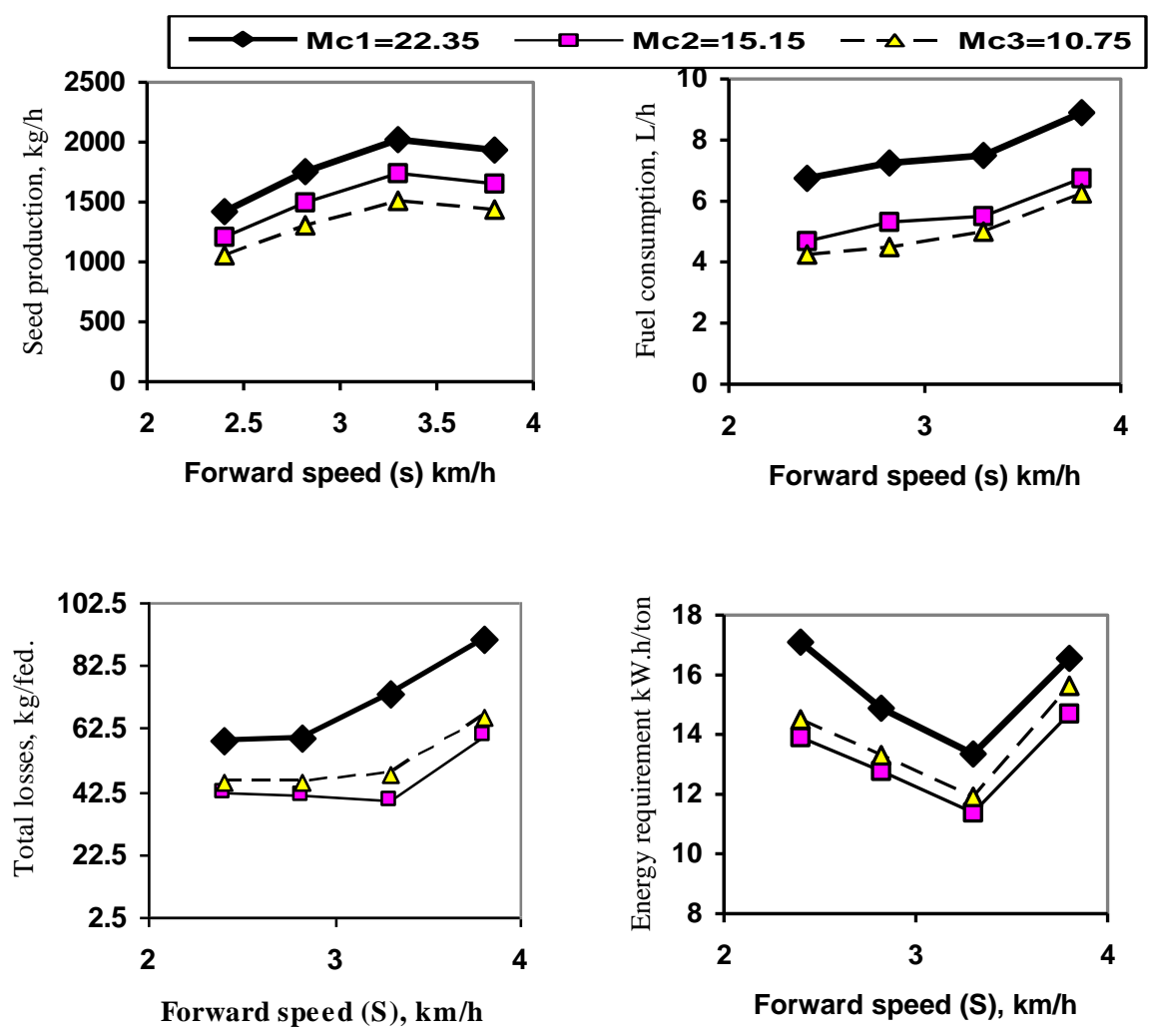

Figure 3. Effect of both forward speed and seed moisture content on seed production $(\mathrm{kg} / \mathrm{h})$, total loss $\mathrm{kg} / \mathrm{fed}$, fuel consumption $(\mathrm{L} / \mathrm{h})$, and specific energy requirements (kW.h/ton).

Effect of combine forward speed and seed moisture content on fuel consumption $\mathrm{L} / \mathrm{h}$ at the recommended parameters of $\mathrm{T}=11.73 \mathrm{~m} / \mathrm{s}$ and $\mathrm{C}$ ratio $=$ 1.5:

\section{Forward speed:}

Figure (3) shows that forward speed has a direct effect on the fuel consumption under the same level of seed moisture content. It is observed that when harvesting at high moisture content of $22.35 \%$ (d.b) by lower forward speed of 2.4 $\mathrm{km} / \mathrm{h}$, the fuel consumption is $6.75 \mathrm{~L} / \mathrm{h}$. Increasing forward speed from $2.4 \mathrm{~km} / \mathrm{h}$ to $2.82 \mathrm{~km} / \mathrm{h}$ increases the consumed fuel to $7.25 \mathrm{~L} / \mathrm{h}$. Any further increment in forward speed causes an increase in fuel consumption. So, the forward speed of $2.4 \mathrm{~km} / \mathrm{h}$ is recommended to obtain the lower volume of consumed fuel.

\section{Moisture content:}

Figure (3) shows that seed moisture content affect the fuel consumption under the same forward speed. It is noted that when harvesting by the forward speed of 2.4 $\mathrm{km} / \mathrm{h}$ under the higher level of seed moisture content of $22.35 \%$ (d.b), the fuel consumption is $6.75 \mathrm{~L} / \mathrm{h}$. Decreasing the seed moisture content to $10.75 \%$ decreases 
the consumed fuel to be $4.68 \mathrm{~L} / \mathrm{h}$ (the decrement is about $2.07 \mathrm{~L} / \mathrm{h}$ ). This result means that the seed moisture content of $10.75 \%$ is recommended as optimum for the lower volume of consumed fuel. When harvesting by the forward speed of $2.4 \mathrm{~km} / \mathrm{h}$. The regression analysis clarified the same trend of results. The following regression equation revealed that there are differences between means of fuel consumption $(L / h)$ as affected by the different levels of machine forward speed $(\mathrm{m} / \mathrm{sec})$ and seed moisture content \% (d.b):

$$
\begin{aligned}
& F_{C}=-2.2+4.98(S)+0.23(M c) \quad\left(R^{2}=0.98\right) \\
& \text { Where: } F_{C}=\text { Fuel Consumption, }(\mathrm{l} / \mathrm{h}) \\
& S \quad=\text { forward speed, }(\mathrm{m} / \mathrm{s}) \\
& M C=\text { seed moisture content, }(\% \text { d.b). }
\end{aligned}
$$

Effect of combine forward speed and seed moisture content on the total harvesting losses $(\mathrm{kg} / \mathrm{fed})$ at the recommended parameters of $\mathrm{T}=11.73$ $\mathrm{m} / \mathrm{s}$ and $\mathrm{C}$ ratio $=1.5$ :

Forward speed:

Figure (3) shows that the forward speed has changeable influence on the total losses under all levels of seed moisture content. It is observed that when harvesting at higher moisture content of $22.35 \%$ (d.b) by the lower forward speed of $2.4 \mathrm{~km} / \mathrm{h}$, the total losses is $58.33 \% \mathrm{~kg} / \mathrm{fed}$. While increasing the forward speed from $2.4 \mathrm{~km} / \mathrm{h}$ to $2.82 \mathrm{~km} / \mathrm{h}$ the total losses increases to $59.37 \mathrm{~kg} / \mathrm{fed}$ (the increment is about 1.4 $\mathrm{kg} /$ fed). Further increasing of forward speed from 2.82 to 3.30 or $3.80 \mathrm{~km} / \mathrm{h}$ leads to increasing the total losses form 59.37 to be $73.56 \mathrm{~kg} /$ fed (the increment is about $14.19 \mathrm{~kg} / \mathrm{fed}$ ) or from $73.56 \mathrm{~kg} /$ fed to be $90.53 \mathrm{~kg} /$ fed (the increment is about 16.07 $\mathrm{kg} / \mathrm{fed}$. This results means that the forward speed) of $2.40 \mathrm{~km} / \mathrm{h}$ is recommended for the lower amount of total losses when harvesting under the higher level of seed moisture content of $22.35 \%$. It can also be noted that the lowest value of total losses of $40.02 \mathrm{~kg} /$ fed is occurred by the forward speed of $3.3 \mathrm{~km} / \mathrm{h}$ under the seed moisture content of $15.15 \%$ (d.b).

\section{Moisture content:}

Figure (3) shows that seed moisture content has changeable effect on the total losses under all levels of forward speed. It is observed that when harvesting by forward speed of $3.30 \mathrm{~km} / \mathrm{h}$ under seed moisture content of $22.35 \%$ (d.b), the total losses is $73.56 \mathrm{~kg} /$ fed while decreasing the seed moisture content from $22.35 \%$ to $15.15 \%$, the total losses decreased to be $40.02 \mathrm{~kg} / \mathrm{fed}$ (the decrement about $33.54 \mathrm{~kg} / \mathrm{fed}$.). Further decrement of seed moisture content from $15.15 \%$ to $10.75 \%$, led to increase the total losses to be $48.00 \mathrm{~kg} / \mathrm{fed}$ (the increment about $8 \mathrm{~kg} / \mathrm{fed}$.). This may be attributed to the seed shattering from the more dried sunflower heads due to the 
mechanical effects of the combine harvester in the field conditions, weather condition and birds. It could be concluded that the seed moisture content of $15.15 \%$ is recommended for the lower amount of total losses when harvesting by the forward speed of $3.3 \mathrm{~km} / \mathrm{h}$. It can also be noted that the lowest value of total losses of 40.02 $\mathrm{kg} /$ fed is occurred under the second seed moisture content of $15.15 \%$ by the forward speed of $3.3 \mathrm{~km} / \mathrm{h}$.

Effect of combine forward speed and seed moisture content on the specific energy requirements (kW.h/ton) at the recommended parameters of $T=11.73 \mathrm{~m} / \mathrm{s}$ and $\mathrm{C}$ ratio $=1.5$.

\section{Forward speed:}

Figure (3) shows that forward speed has changeable influence on the specific energy requirements under the all levels of seed moisture content. It is observed that when harvesting under higher moisture content of $22.35 \%$ (d.b) by the lower forward speed of $2.4 \mathrm{~km} / \mathrm{h}$ the specific energy requirements is $17.10 \mathrm{~kW} . \mathrm{h} / \mathrm{ton}$. While increasing the forward speed to $2.82 \mathrm{~km} / \mathrm{h}$, the specific energy requirements slightly decreases to be $14.88 \mathrm{~kW} . \mathrm{h} /$ ton (the decrement was about $2.22 \mathrm{~kW} . \mathrm{h} /$ ton). Further increase of forward speed to $3.30 \mathrm{~km} / \mathrm{h}$, the required energy decreases to be 13.35 $\mathrm{kW} . \mathrm{h} /$ ton the decrement $1.50 \mathrm{~kW} . \mathrm{h} / \mathrm{ton}$. More increase in forward speed to be 3.80 $\mathrm{km} / \mathrm{h}$ increases the specific energy required suddenly to be $16.55 \mathrm{~kW} . \mathrm{h} / \mathrm{ton}$ with an increment of $3.20 \mathrm{~kW} . \mathrm{h} / \mathrm{ton}$. This behavior of the combine forward speed vs. the energy required for harvesting a unit mass of sunflower seed might be explained by increasing the combine forward speed led to decreasing the time required for harvesting a unit mass (ton) of sunflower seeds and then the specific energy decreases consequently. The continuity of increasing for combine forward speed led to increasing in the feeding mass towards the threshing system till the baling process happen. So, the combine productivity decreases and the specific energy increase. In this time, the combine forward speed must be reduce to get an equilibrium between the feed mass entered to the threshing drum and the time of threshing itself. This result indicate that the forward speed of $3.30 \mathrm{~km} / \mathrm{h}$ is recommended for the lower value of the specific energy requirements specially at seed moisture content of $15.15 \%$ d.b.

\section{Moisture content:}

Figure (3) shows that the seed moisture content has a considerable influence on the specific energy required using all levels of forward speed under investigation. It is obvious that when harvesting by the forward speed of $3.30 \mathrm{~km} / \mathrm{h}$ under the higher seed moisture content of 22.35 (d.b), the specific energy required is $13.35 \mathrm{~kW}$.h/ton. Decreasing the seed moisture content to $15.15 \%$ decreases the specific energy 
required to the value of $11.38 \mathrm{~kW} . \mathrm{h} / \mathrm{ton}$. The decrement was about $1.67 / \mathrm{kW} . \mathrm{h} / \mathrm{ton}$. Further decrement of seed moisture content lead to slight increasing in the specific energy required to be $11.92 \mathrm{~kW} . \mathrm{h} /$ ton (the increment was $0.43 \mathrm{~kW} . \mathrm{h} / \mathrm{ton}$ ). This result indicates that the seed moisture content of $15.15 \%$ is recommended to assure the lowest value of energy required when harvesting by the forward speed of $3.30 \mathrm{~km} / \mathrm{h}$.

\section{Effect of combine forward speed and seed moisture content on total harvesting efficiency \%:}

The total harvesting efficiency (header, threshing, separating and cleaning efficiency) is increasing slightly with increasing of combine harvester forward speed till the speed of $3.3 \mathrm{~km} / \mathrm{h}$, where it begins to decrease sharply under the levels of seed moisture content used in this investigation . This trend is clear in Figure (4). The highest value of total efficiency of $97.27 \%$ was recorded at $3.3 \mathrm{~km} / \mathrm{h}$ combine forward speed under $15.15 \%$ (d.b) seed moisture content, while the low value of $95.75 \%$ obtained at seed moisture content of $22.35 \%$ (d.b) at the same forward speed .

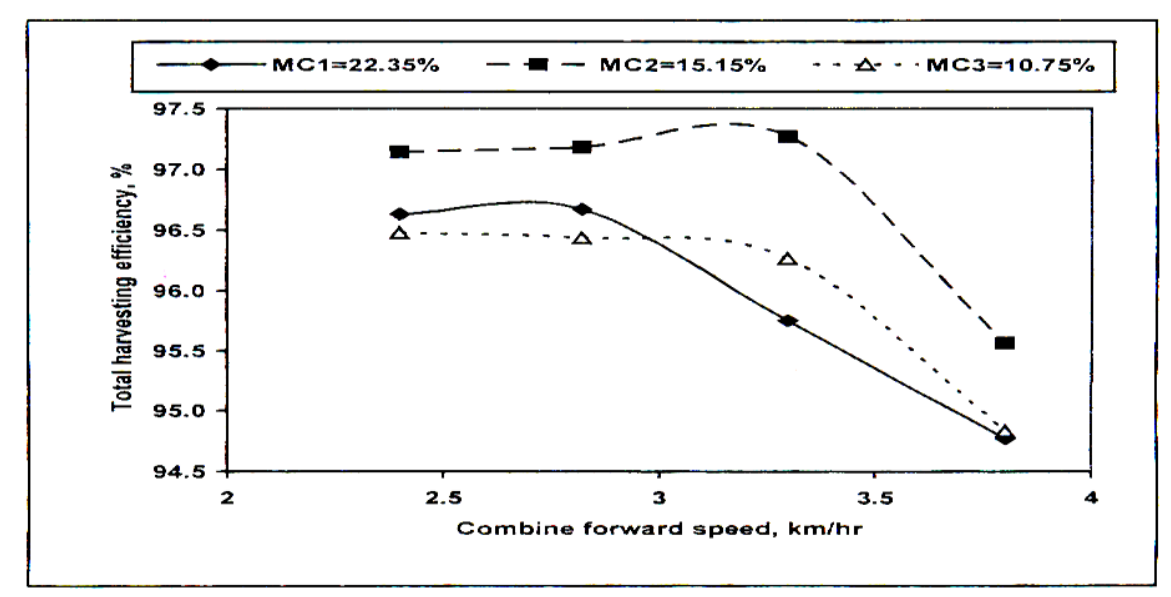

Figure 4. Effect of combine harvester forward speed and seed moisture contents on total harvesting efficiency, \%.

\section{Cost evaluation for the modified sunflower combine harvester:}

Referring to the data in table (2) and table (3), it could be seen that the minimum criterion costs of 68342 EGYP / y were occurred at the $1.22 \mathrm{fed} / \mathrm{h}$ field capacity with $15.15 \%$ seed moisture content. The condition

1.22 fed / $\mathrm{h}$ field capacity and $15.15(\% \mathrm{db})$ seed moisture content may be recommended for obtaining the minimum criterion costs when harvesting sunflower mechanically. 
Table 2. Fixed and operating costs

\begin{tabular}{|l|c|}
\hline Fixed Costs: & EGYP /h \\
\hline Deprecation & 22.50 \\
Interest an investment & 13.75 \\
Taxes, Insurance and sheltering & 5.00 \\
\hline Total Fixed costs & 41.25 \\
\hline Operating costs: & EGYP /h \\
\hline Repair and maintenance & 18.00 \\
Labor costs & 5.00 \\
Fuel cost & 3.00 \\
Oil and filters cost & 0.80 \\
\hline Sub-total operating costs & 23.50 \\
\hline Fixed Costs: & EGYP /h \\
\hline Deprecation & 22.50 \\
Interest an investment & 13.75 \\
Taxes, Insurance and sheltering & 5.00 \\
\hline Total Fixed costs & 41.25 \\
\hline Operating costs: & EGYP /h \\
\hline Repair and maintenance & 18.00 \\
Labor costs & 5.00 \\
Fuel cost & 3.00 \\
Oil and filters cost & 0.80 \\
\hline Sub-total operating costs & 23.50 \\
\hline Sub-total costs & 64.75 \\
\hline
\end{tabular}

Table 3. effect of both field capacity and seed moisture content on

\begin{tabular}{|c|c|c|c|c|c|}
\hline \multirow{2}{*}{$\begin{array}{c}\text { Field } \\
\text { capacity } \\
\text { fed/h }\end{array}$} & \multirow{2}{*}{$\begin{array}{c}\text { Annual } \\
\text { working } \\
\text { hours h/y }\end{array}$} & \multirow{2}{*}{ Cost items } & \multicolumn{3}{|c|}{ Seed Moisture Content (\% d.b) } \\
\cline { 4 - 6 } & & $\mathrm{MC}_{1}(22.35)$ & $\mathrm{MC}_{2}(15.15)$ & $\mathrm{MC}_{3}(10.75)$ \\
\cline { 4 - 6 } 0.85 & \multirow{2}{*}{244.8} & Losses cost & 15925 & 15190 & 14455 \\
& & Criterion cost & 70464 & 69729 & 68994 \\
\hline \multirow{2}{*}{1.05} & \multirow{2}{*}{240.5} & Losses cost & 20485 & 17111 & 17352 \\
& & Criterion cost & 74917 & 71543 & 71784 \\
\hline \multirow{2}{*}{1.22} & \multirow{2}{*}{245.9} & Losses cost & 29520 & 13776 & 21894 \\
& & Criterion cost & 84086 & 68342 & 76460 \\
\hline \multirow{2}{*}{1.18} & \multirow{2}{*}{242.7} & Losses cost & 32319 & 274559 & 29646 \\
& & Criterion cost & 86804 & 81944 & 84131 \\
\hline
\end{tabular}

$\mathrm{EGY} / \mathrm{h}=\mathrm{EGYP} / \mathrm{h}, \mathrm{EGY} / \mathrm{f}=\mathrm{EGYP} / \mathrm{fed}$ and $\mathrm{EGY} / \mathrm{t}=\mathrm{EGYP} / \mathrm{ton}$.

The price of $1 \mathrm{~kg}$ seeds = 1.5 EGYP- Fu, gr, Lu oil = fuel, grease and lubrication oil. 


\section{REFERENCES}

1. Anil-Joshi, T. Guruswany; S.R. Deasi; J.T. Basavaraj and A. Joshi. 1998. "Effect of cylinder speed and feed rate on the performance of thresher. College of Agricultural Engineering Raichcr-584101, India. Karnataka-Journal of Agricultural Sciences. 1998, 11: 4, 1120-1123, 4 ref.

2. Arnul-Atares, P. 1990. Now developments in grain harvesting machinery. Instituto Tecnico de Gestion del Cereal de Pamplona. Pamplona, Spain, MAquinas-YTractores-Agricola. 1990, 1: 5, 24-35, 8 ref.

3. Awady, M.N., E.Y. Ghoniem and A.I. Hasim. 1982. A critical comparison between sheat combine harvester under Egyptian condition. R.S. No. 1920 Ain Shams U.J. 1982.

4. Baev, V.I.; H. Borodmand and E.N. Zhivopistsev. 2001. Energy evaluation of electro technology in plant production. Vologorad Skha, Russia,. Mekhanizatsiya. iElktritik atsiya-sel'skogo-Khozyaistva, 2001, No. 4, 8-11.

5. Counselor and Attach Reports. Official Statistics USDA Estimates, 2002.

6. Culpin, C. 1986. Farm machinery "combine harvesting" . Tenth edition. pp. 212223.

7. Dobresc, C., E. Nicsuluscu and H. Beghes. 1974. Sunflower Mechanical Harvesting in Romania, Proceedings of the Sixth International Sunflower Conference, July 2224, Bucharest, Romania.

8. Dragos, T. 1979. Farm machinery equipments. handbook. Ministry of Education. Bucharest pp. 246.

9. El-Sayed, G.H., M.A. El-attar and E.M. Arif. 2002. Mechanical harvesting of sunflower using the general purpose combine. The $10^{\text {th }}$ Annual conference of the Misr Society of Ag. Eng., 16-17 Oct., 2002: 155-172.

10. FAOSTA. Database Results CSV File-FAO 2004.

11. Georgiey, D. (1990). Study of the work of combine harvesters with an axial-flow threshing drum for sunflower. Institute Po Pshenitsata i si "nechogleda" Dobrudzhae, General (Toschevo, Bulgaria. Selskostopanska-Tekhnika, 1990, 27, 3, 3-00, 7 ref.

12. Kapustin, V.P. and S.A. Kunakov. 2004. Physical and mechanical proprieties of sunflower". Tombvoskii Gousdarstvenngi Tekhnicheskkii Universitet, TambvoRussia. Mekhanizatsiya-i-Elecktrifikatsi-Sel'-Skogo-Khozyaistva, (6): 7-9 Moscow, Russia.

13. Kaul, M.N. and P.E. Egbo. 1985. Introduction to agriculture mechanization "Management and Cost Analysis" First published, pp. 172-173. 
14. Kepner, R.A.; R. Bainer and E.L. Barger. 1982. Principle of farm machinery, third edition. The AVI Publishing Co. Inc. Westport. Connecticut, 392-428.

15. Kumar, R.J. and R. Goss. 1977. Alfalfa seed harvesting efficiencies and simulation grain and forage harvesting conference". Ames, Iowa U.S.A. pp. 124-130.

16. Ministry of Agriculture and Land Reclamation. 1990. Sunflower particularities and cropping, pp. (3-4, 11, 26 \& 41-44).

17. Mohamed, A.M. 1991. Mechanization of sunflower under Egyptian conditions. M.Sc. Agric. Eng. Dept. Faculty of Agric. Zagazig Univ. pp. 93-95.

18. Moskalenko, V.I. 1976. Main trends in the production of sunflower harvesting machines. Proceedings of the $7^{\text {th }}$ International Sunflower Conference, 27 June-3 July 1976.

19. Naravani, N.B. 1987. Investigations on the performance of Mysore Mini Thresher for efficient threshing of sunflower corp. Agric. Eng. Inst. Raichur-584101 (Karnatoka). India, The role of Agricultural Engineering in dry land Agriculture. Proceedings of the $23^{\text {rd }}$ Annual Convention of the Indian Society of Agricultural Engineers. Jaba (Pur. India. 9-11 Mach 1987, 62-66' 3 ref.

20. Schuler, R.T., V.L. Hirning, Hofman and D.R. Lundstorm. 1976. Harvesting, handling and storage of seed sunflower. Association of America, Forage North Dakuta, USA.

21. Shalaby, S. A. M. 2006. Development of harvesting system to be suitable for sunflower harvesting on small holdings. Ph. D. thesis, Agri. Eng. Menoufyia Unv.

22. Szendro, P. and I. Szabo. 1990. Reduction of the loss of sunflower harvesting. Hungarian-Agric. Engineering. No. 3. pp. 20-21.

23. Taieb, A.Z. 1990. The demand and constraints of energy utilization in sugar beet crop production. Cairo Univ. Ph. D., (Agric., Eng.).

24. Toth, J. and M. Liker. 1992. New results obtained in developing the energy saving technology far sunflower harvesting. Hungarian Institute of Agric. Eng. TessedikSamuel Utca. 4, 2100 Godollo Hungary. Hungarian Agric. Eng. 1992 No. 5, 17-18.

25. Trubilin,.E.I. and V.S. Kravchenko. 2001. The feasibility of harvesting sunflower with the reaper units of grain combines. : Tekhnika-v-Sel'-skom-Khozyaistve. 2001, (1): 20-22. Moscow, Russia: Mezhdunarodnyi Tsentr Nauchnoi i Tekhnicheskoi Informatsii. 
تقييم اداء آلة حصاد الحبوب و المعدلة لحصاد محصول عباد الثمس

جمال حسن السيد' محمد عبد الفتاح عبد المقصود' سمير عبد الحميد مصطفى شلبى'

$$
\text { r فعه العوث الهنسة الزراعية - مركز البحوث الزراعية - الجيزة }
$$

أجريت هذه الدراسة فى محطة البحوث الزراعية بالجميزه بالمزرعة البحثية فى مواسم حصاد عباد

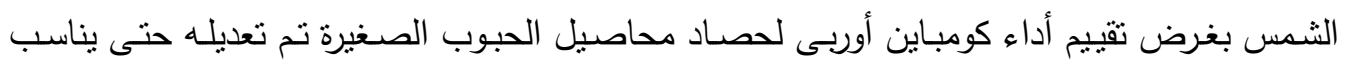
حصاد أقراص محصول عباد الثمس. تم تقييم الأداء بعد تعديل مقدمة الحصاد و أسطوانة الدراس من خلاد دراسة تأثنير العوامل الاتيه:

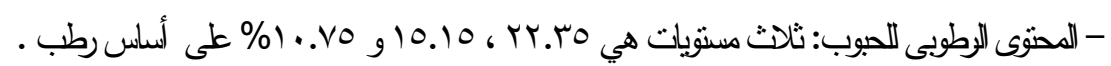

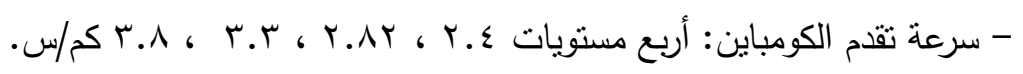

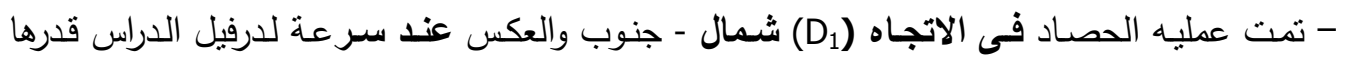
(1.VT) العوامل الثلاثة تم تحديدها في درا سه سابقة.

تقييم أداء آلة الحصاد المعدلة (الكومباين):

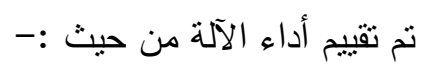
- السعة الإنتاجية

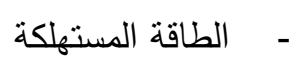
-

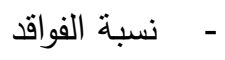
-

و ذلك عند مستويات مختلفة من الرطوبة و سرعات أمامية مختلفة للآلة و اتجاه الحصاد .

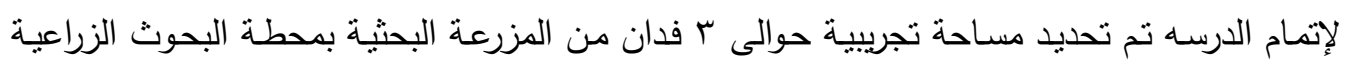

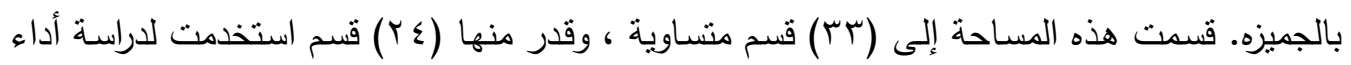

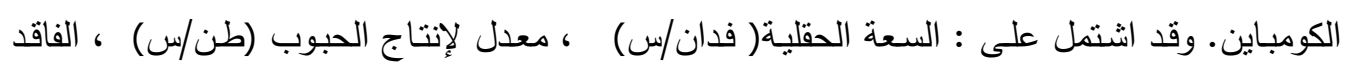

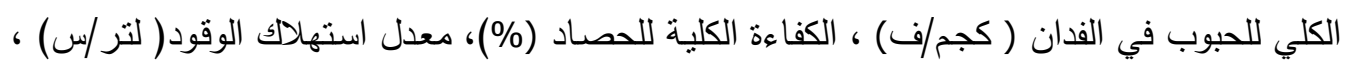

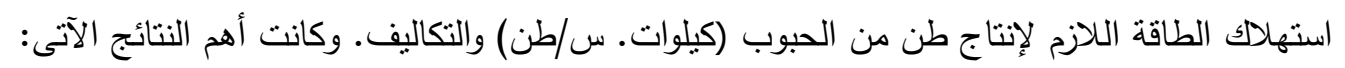


أثنارت النتائج الى أن أقل معدل لإنتاج الحبوب كان (†1 . ـا طن/س) وتم الحصول عليه بالحصاد

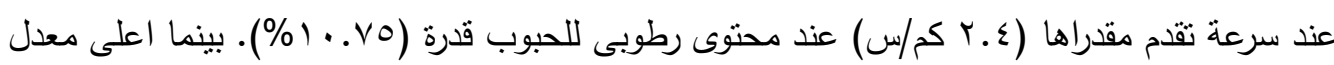

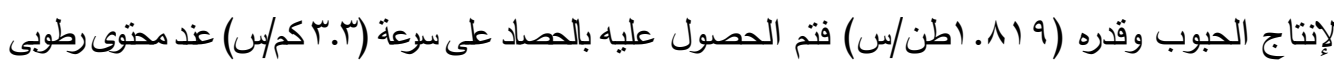

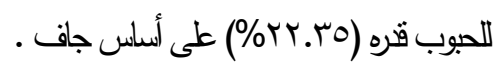

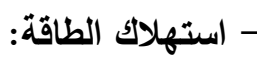

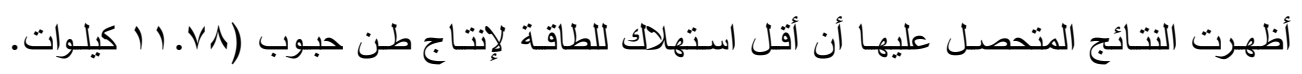

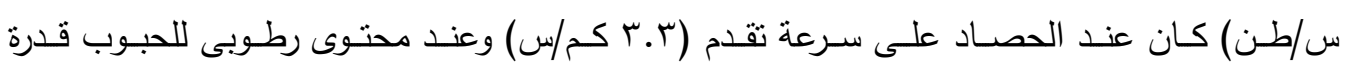

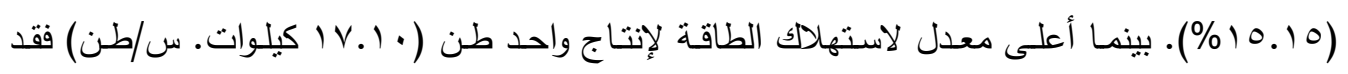

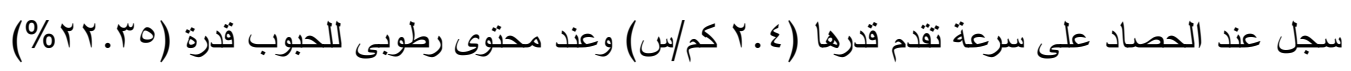

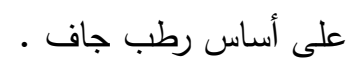

-

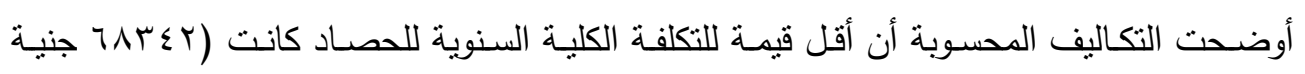

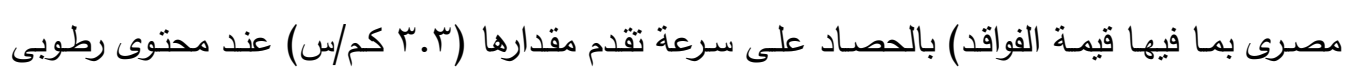

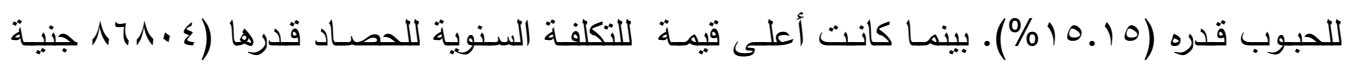

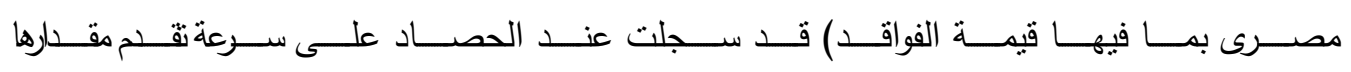

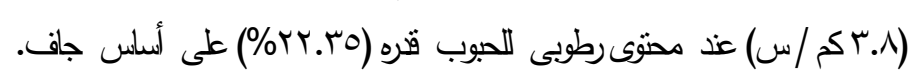

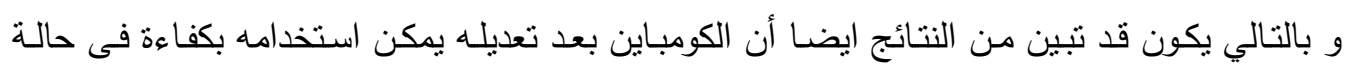

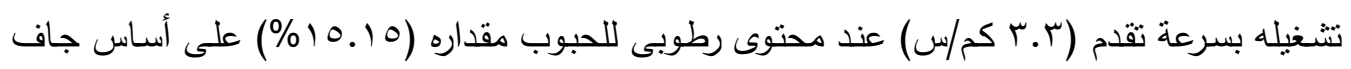

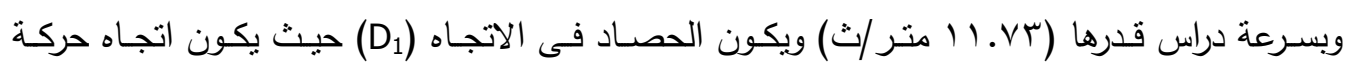

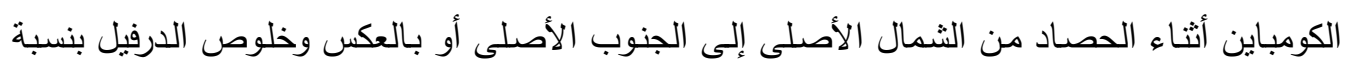

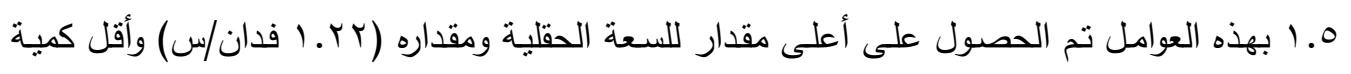

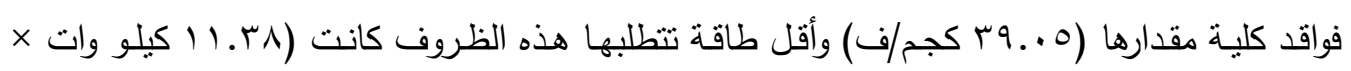

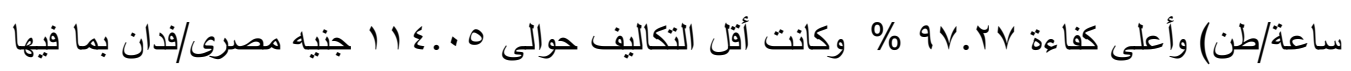
• قيمة الفواقد 